\title{
Some findings on the mechanism of adaptation of the intestine to calcium deficiency
}

\author{
BY M. WINTER \\ Department of Pathophysiology, Semmelweis University Medical School, \\ Budapest, Hungary \\ E. MORAVA \\ National Institute of Nutrition, Budapest, Hungary \\ TAMARA HORVATH, G. SIMON AND J. SOS \\ Department of Pathophysiology, Semmelweis University Medical School, \\ Budapest, Hungary \\ (Received 20 September 1971 - Accepted 28 fanuary 1972)
}

\begin{abstract}
1. The rate of absorption of calcium was measured in vivo by an isotope technique in rats given either a normal or a low-Ca diet.

2. Increasing the amount of $\mathrm{Ca}$ injected into the lumen of the intestine decreased the rate of Ca absorption. When the dose was greater than roo-r $50 \mu \mathrm{g}$ Ca the degree of absorption was a linear function of the $\mathrm{Ca}$ concentration in both duodenum and jcjunum.

3. In rats given a $\mathrm{Ca}$-deficient diet for 2 weeks the absorptive capacity of both the duodenum and jejunum was significantly enhanced. Judged by the changes in the rate of absorption with different doses, some saturable mechanism seemed to be involved in this phenomenon.

4. Parathyroidectomy before adaptation to Ca deficiency prevented the increase in Ca absorption in Ca-deficient rats but diminished it only slightly in rats given a normal diet. Parathyroidectomy performed after the development of adaptation to $\mathrm{Ca}$ deficiency also decreased $\mathrm{Ca}$ transport across the intestine, which suggests that the parathyroids are necessary for increasing the capacity of the rat intestine to absorb $\mathrm{Ca}$.
\end{abstract}

Recent advances in the understanding of calcium metabolism have led us to the conclusion that an important factor determining normal serum and tissue Ca concentration is the rate of $\mathrm{Ca}$ absorption from the intestine. By increasing the absorptive capacity of the gut, the body can adapt itself to a restriction in Ca intake or can satisfy an increase in $\mathrm{Ca}$ requirement.

Nicolaysen and his colleagues have studied this phenomenon in rats and reported that deprivation of $\mathrm{Ca}$ enhanced $\mathrm{Ca}$ absorption in vivo (Nicolaysen, Eeg Larsen \& Malm, I953; Nicolaysen, 1956). However, they could not explain the mechanism involved in this change, nor show whether or not it depended on the presence of some hormone-like substance.

About a decade ago numerous studies were made of $\mathrm{Ca}$ transport in the intestine, by methods using inverted intestinal sacs. It has been suggested that, in rats, $\mathrm{Ca}$ normally passes through the duodenal wall by means of an active mechanism but through the jejunal wall by passive diffusion (Schachter \& Rosen, r959; Schachter, Kimberg \& Schenker, 1961). After giving a diet deficient in $\mathrm{Ca}, \mathrm{Ca}$ transport in the jejunum is also 
by an active mechanism, transfer of $\mathrm{Ca}$ being increased along the whole small intestine (Dowdle, Schachter \& Schenker, I960; Kimberg, Schachter \& Schenker, I96r).

On the other hand, numerous reports have dealt with the mode of action of vitamin $\mathrm{D}$ in the intestine. It has been established that vitamin $\mathrm{D}$ promotes the synthesis of a specific protein (or proteins) in the intestinal wall of chicks and rats which may have an important role in Ca absorption (Taylor \& Wasserman, I965, 1967, I969; Wasserman \& Taylor, I968; Wasserman, Corradino \& Taylor, 1969; Melancon \& DeLuca, 1970). When the diet has been deficient in $\mathrm{Ca}$, the amount of the specific protein(s) synthesized also increases in parallel with the increase in $\mathrm{Ca}$ absorption (Taylor \& Wasserman, I969; Wasserman \& Taylor, I968; Taylor \& Wasserman, 1970).

In spite of the numerous findings on the adaptation of the intestine to $\mathrm{Ca}$ deficiency, the underlying mechanism is not fully understood. Two important questions need to be answered: how the need of the body for $\mathrm{Ca}$ is linked to the intestinal transport mechanism and which component of the transport system is responsible for the intestine's increased capacity to absorb Ca.

The experiments described here were designed to obtain information on both these questions. Our results confirmed that the parathyroids were necessary for adaptation to a low-Ca diet and suggested that a saturable component of the transport mechanism would change during adaptation.

\section{EXPERIMENTAL AND RESULTS}

\section{Animals and diets}

Male rats, weighing $60-80 \mathrm{~g}$ at the beginning of the experiment, were used. They were given ad lib. a semi-synthetic diet for the experimental period. The detailed percentage composition of the low-Ca diet was: casein 20 , wheat meal 23 , starch 45 , sunflower-seed oil 7 , salt mixture + vitamin mixture 5 . The salt mixture provided, per $\mathrm{kg}$ diet: $\mathrm{MgCl}_{2} 9.480 \mathrm{~g}, \mathrm{NaCl}$ I0.863g, $\mathrm{KH}_{2} \mathrm{PO}_{4} 22.516$ g, $\mathrm{Na}_{2} \mathrm{HPO}_{4} 6.583 \mathrm{~g}, \mathrm{FeCl}_{3} 26 \mathrm{Img}$, $\mathrm{MnCl}_{2}$ I $22 \mathrm{mg}$, zinc acetate ${ }_{5} 8 \mathrm{mg}$, copper acetate $\mathrm{I} 3 \mathrm{mg}, \mathrm{As}_{2} \mathrm{O}_{3} 3 \cdot 2 \mathrm{mg}$, KI I. $3 \mathrm{mg}$. The vitamin mixture provided, per $\mathrm{kg}$ diet: cholecalciferol 2400 i.u., vitamin $\mathrm{A}$ 4800 i.u., cyanocobalamin $2.4 \mu \mathrm{g}$, folic acid $0.48 \mathrm{mg}$, pyridoxine hydrochloride $0.96 \mathrm{mg}$, thiamin hydrochloride $2.4 \mathrm{mg}$, riboflavin $2.4 \mathrm{mg}$, calcium pantothenate $4.8 \mathrm{mg}$, nicotinamide $24^{\circ} \circ \mathrm{mg}$, ascorbic acid $96 \mathrm{mg}$, biotin $0^{\circ} 2 \mathrm{mg}$, menaphthone $\mathrm{I}^{\circ} \mathrm{O} \mathrm{mg}$.

In the normal diet, calcium lactate was added to the low-Ca diet, at the expense of starch, to make the Ca content $0.6 \%$. The Ca content of the low-Ca diet was $0.1 \%$. Each diet contained $0.4 \%$ phosphorus.

\section{Experimental procedures}

The rats were fasted for $20 \mathrm{~h}$ before the experiment; water was given $a d$ lib. Under sodium pentobarbital (Nembutal) anaesthesia, the abdomen was opened through a paracostal incision, $2-3 \mathrm{~cm}$ long, and, by means of ligatures, a duodenal sac and a jejunal sac were prepared. Their lengths were kept constant as far as possible; that of the duodenal sac varied between 6 and $8 \mathrm{~cm}$ and that of the jejunal between ro and $12 \mathrm{~cm}$. The duodenal sac was prepared $2-3 \mathrm{~cm}$ distal to the pylorus, the jejunal loop 
Table I. Influence of length of period on a low-calcium diet on Ca absorption of the intestine of rats after administration of ${ }_{15} 5 \mathrm{\mu g}$ and $100 \mu \mathrm{g}{ }^{45} \mathrm{Ca}$ into the duodenum and jejunum respectively

(Mean values and standard deviations for fourteen rats/group)

$\begin{array}{cccc}\text { Diet } & \begin{array}{c}\text { Duration } \\ \text { of diet (d) }\end{array} & \text { In duodenum } & \text { In jejunum } \\ \text { Normal } & 14 & 37 \cdot 6 \pm 8 \cdot 0 & 32 \cdot 9 \pm 8 \cdot 2 \\ \text { Low-Ca } & 3 & 50 \cdot 3 \pm 21 \cdot 2 \mathrm{NS} & 34 \cdot 8 \pm 9 \cdot 0 \\ \text { Low-Ca } & 14 & 62 \cdot 6 \pm 12 \cdot 0^{* * *} & 44 \cdot 0 \pm 12 \cdot 3^{* *} \\ \text { NS, not significant; ** } & P<0 \cdot 02 ; * * * & P<\text { o.oor. (Compared with the normal group.) }\end{array}$

was ligated at $5^{-6} \mathrm{~cm}$ distal to the end of the proximal sac. Special care was taken to avoid damaging the blood vessels of the intestine, any rats suspected of having sustained damage were discarded. A known amount of calcium chloride, labelled with ${ }^{45} \mathrm{Ca}$, was injected in $0.25 \mathrm{ml}$ physiological saline into both sacs, which were then closed and replaced in the abdominal cavity. The abdomen was closed with several sutures. The amount of $\mathrm{Ca}$ administered was $\mathrm{I}_{5} \mathrm{\mu} \mu \mathrm{g}$ into the duodenum and $100 \mu \mathrm{g}$ into the jejunum, except in the experiment where several different doses of Ca were tested. Since normal $\mathrm{Ca}$ absorption is more intense in the duodenum than in the jejunum, a larger dose of $\mathrm{Ca}$ was injected into the duodenum so as to obtain similar values for the percentage absorption. The rats were kept at a temperature of $26-28^{\circ}$ for 20 min. Then the abdomen was reopened, the loops were excised and the amount of the ${ }^{45} \mathrm{Ca}$ dose that remained was determined using an end-window Geiger-Muller tube. The percentage ${ }^{45} \mathrm{Ca}$ absorbed was calculated.

The statistical significance of the findings was evaluated by Student's $t$ test, and the results are given as mean values and standard deviations.

'To study the effect of the lack of parathyroid hormone, rats were surgically parathyroidectomized, the controls undergoing a sham operation. The effectiveness of the operation was checked $3 \mathrm{~d}$ later and the day before the test of absorption by determining serum $\mathrm{Ca}$ concentration by titration with EDTA in a Beckman-Spinco micro-analytical system. Only those rats were used in which the serum Ca was at least $2 \mathrm{mg} / \mathrm{roo} \mathrm{ml}$ less than the control level.

\section{Time-course of the development of adaptation to a low-Ca diet}

Forty-two rats were divided into three groups of fourteen animals each. The first group was given the normal diet for $\mathrm{I} 3 \mathrm{~d}$; the second group was given the normal diet for ro $\mathrm{d}$ and the low-Ca diet during the next $3 \mathrm{~d}$; the third group was given the low$\mathrm{Ca}$ diet during the whole experimental period. Examination of $\mathrm{Ca}$ absorption on the I 4 th day showed that the $3 \mathrm{~d}$ of $\mathrm{Ca}$ deprivation resulted in a moderate increase in $\mathrm{Ca}$ absorption in the duodenum but in no change in that in the jejunum. The 2-week period of $\mathrm{Ca}$ deprivation enhanced both duodenal and jejunal $\mathrm{Ca}$ absorption (see Table I). During further experiments, $\mathrm{Ca}$ deprivation for 2 weeks was used. 


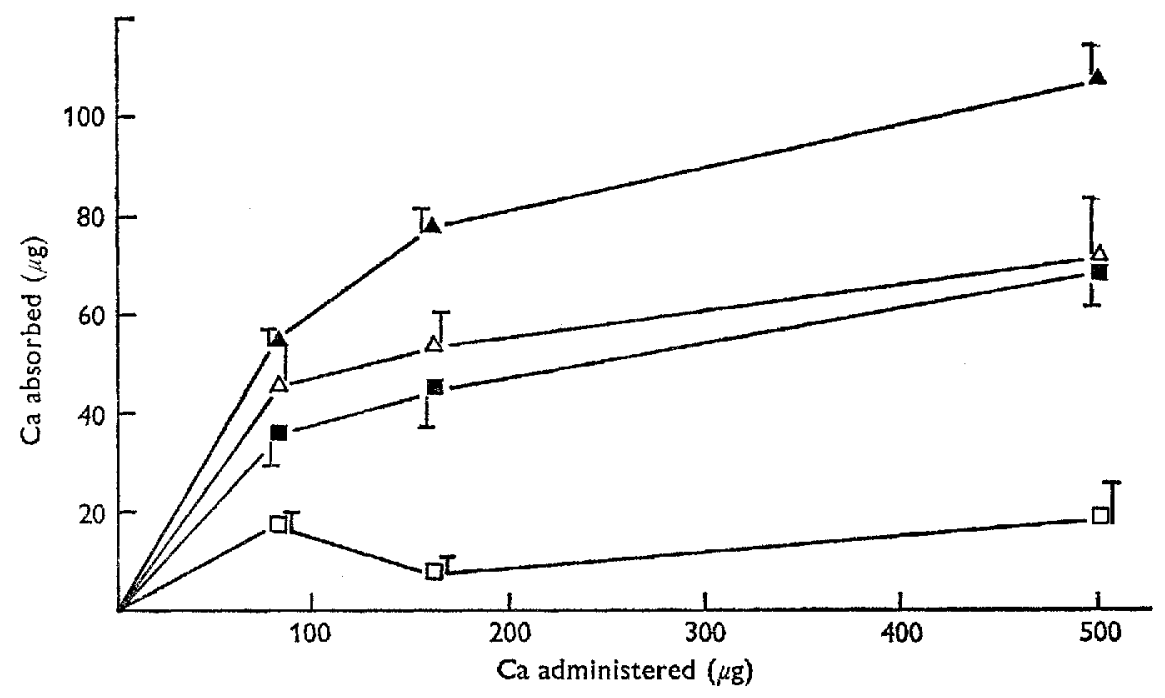

Fig. I. Influence of the amount of calcium administered into the intestine on duodenal and jejunal absorption of $\mathrm{Ca}$ in normal and $\mathrm{Ca}$-deficient rats. $\square-\square$, normal, jejunum;

Ca-deficient, jejunum; $\Lambda-\Lambda$, normal, duodenum; $\Delta \longrightarrow \mathbf{A}$ Ca-deficient, duodenum. (Mean values with their standard errors represented by vertical bars.)

\section{Absorption of different amounts of $\mathrm{Ca}$ administered into the intestine of rats given either a normal or a low-Ca diet}

Seventy-eight rats were divided into two groups, one of which was given the normal and the other the $\mathrm{Ca}$-deficient diet for 2 weeks. At the end of this period the rate of $\mathrm{Ca}$ absorption was examined after three different doses of $\mathrm{Ca}$ had been administered to groups of thirteen animals each. The amount of $\mathrm{Ca}$ absorbed was plotted against the dose injected into the lumen (Fig. I). It is seen that the slope of all the four lines diminished as the dose was increased. The rate of absorption was higher in $\mathrm{Ca}$ deficient animals with all doses of Ca used. The slope of the lines was more pronounced when the dose was low and only this part of the lines was influenced by the experimental conditions. The further parts of the lines are flattened and run parallel with each other; their slope appears to have been unaffected by the diet. This shows that when the dose reaches a certain size the amount of $\mathrm{Ca}$ absorbed is a linear function of the luminal $\mathrm{Ca}$ concentration.

\section{Effect on Ca absorption of parathyroidectomy performed when the low-Ca diet was first offered}

Parathyroidectomy or a sham operation was performed on fifty rats. After the serum $\mathrm{Ca}$ concentration of each rat had been determined, the animals were divided into four groups and were given the normal or the low-Ca diet as shown in Table 2, each diet being offered to both parathyroidectomized and sham-operated animals. The shamoperated groups contained ten rats, the parathyroidectomized groups consisted of fifteen animals each. Two weeks later, serum $\mathrm{Ca}$ concentrations were determined again (these results arc also shown in Table 2 ) and the rate of $\mathrm{Ca}$ absorption was 
Table 2. Effect of prior parathyroidectomy (PTX) on the adaptation of intestinal calcium absorption in rats given the low-Ca diet for 2 weeks after administration of $\mathrm{I} 5 \mathrm{O} \mu \mathrm{g}$ and $100 \mu \mathrm{g}{ }^{45} \mathrm{Ca}$ into the duodenum and jejunum respectively

(Mean values and standard deviations)

\begin{tabular}{|c|c|c|c|c|c|}
\hline \multirow[b]{2}{*}{ Diet } & \multirow[b]{2}{*}{ Operation } & \multicolumn{2}{|c|}{ Ca absorbed (as \% of dose) } & \multirow{2}{*}{$\begin{array}{c}\text { Serum Ca } \\
(\mathrm{mg} / \mathrm{I} \text { oo } \mathrm{ml})\end{array}$} & \multirow{2}{*}{$\begin{array}{l}\text { No. of } \\
\text { animals }\end{array}$} \\
\hline & & In duodenum & In jejunum & & \\
\hline Normal & Sham & $5 I \cdot I \pm 8 \cdot 3$ & $36 \cdot 6 \pm 35 \cdot 5$ & $8.77 \pm 0.83$ & IO \\
\hline Low-Ca & Sham & $63.5 \pm 77^{* * * *}$ & $54 \cdot 2 \pm 13.6 *$ & $8 \cdot 13 \pm I \cdot 3 I$ & IO \\
\hline Low-Ca & PTX & $45 \cdot 6 \pm 12 \cdot 1$ & $35^{\cdot 6 \pm I 9^{\prime I}}$ & $4.64 \pm 0.87$ & I 5 \\
\hline Normal & PTX & $47.0 \pm 8.7$ & $34 \cdot 5 \pm 22 \cdot 6$ & $5.90 \pm 0.91$ & I5 \\
\hline
\end{tabular}

Table 3. Effect of parathyroidectomy $(P T X)$ performed on the $\mathrm{1} 4$ th or $\mathrm{1} 8$ th day of a low-calcium diet on intestinal Ca absorption in rats after administration of $150 \mu g$ and $100 \mu \mathrm{g}{ }^{45} \mathrm{Ca}$ into the duodenum and jejunum respectively

(Mean values and standard deviations)

\begin{tabular}{|c|c|c|c|c|c|}
\hline \multirow[b]{2}{*}{ Diet } & \multirow[b]{2}{*}{ Operation } & \multicolumn{2}{|c|}{$\mathrm{Ca}$ absorbed (as \% of dose) } & \multirow{2}{*}{$\begin{array}{c}\text { Serum Ca } \\
(\mathrm{mg} / \mathrm{I} 00 \mathrm{ml})\end{array}$} & \multirow{2}{*}{$\begin{array}{l}\text { No. of } \\
\text { animals }\end{array}$} \\
\hline & & In duodenum & In jejunum & & \\
\hline Normal & Sham & $46 \cdot 5 \pm 8 \cdot 7$ & $42 \cdot 1 \pm 10 \cdot 6$ & $9 \cdot 1 \pm 0.7$ & 12 \\
\hline Low-Ca & Sham & $55 \cdot 7 \pm 7 \cdot 8 * *$ & $50 \cdot 5 \pm 8 \cdot 4^{*}$ & $9 \cdot 3 \pm 0.5$ & $\mathrm{I} 4$ \\
\hline Low-Ca & $\begin{array}{l}\text { PTX at } \\
\text { I } 8 \text { th day }\end{array}$ & $48 \cdot 6 \pm$ I I 8 & $39 \cdot 9 \pm 9 \cdot 9$ & $5 \cdot 7 \pm 0.6$ & 18 \\
\hline Low-Ca & $\begin{array}{l}\text { PTX at } \\
\text { I } 4 \text { th day }\end{array}$ & $46 \cdot 4 \pm 7 \cdot 1$ & $42 \cdot 6 \pm 8 \cdot 5$ & $6 \cdot 3 \pm 0.5$ & I I \\
\hline
\end{tabular}

examined. The results showed that parathyroidectomy prevented the enhancement of $\mathrm{Ca}$ absorption in the $\mathrm{Ca}$-deficient group. On the other hand, it had only a slight effect on the absorption in the rats on the normal diet.

\section{Effect on Ca absorption of parathyroidectomy performed on the I4th day or $\mathrm{I} 8$ th day of $\mathrm{Ca}$ deprivation}

Fifty-five rats were divided into four groups. One group was given the normal diet, the other three the Ca-deficient diet. On the 14 th or the 18 th day of the dietary regimen parathyroidectomy was performed on two Ca-deficient groups. On the 2Ist day blood was taken for serum $\mathrm{Ca}$ determination and the rate of $\mathrm{Ca}$ absorption was examined. At this time the number of animals of the individual groups were: normal, sham-operated, $\mathrm{I} 2$; low-Ca, sham-operated, $\mathrm{I}_{4}$; low-Ca, operated on the $\mathrm{I} 8$ th day, $\mathrm{I} 8$; low-Ca, operated on the $\mathrm{I} 4^{\text {th }}$ day, II. As results in Table 3 show, the removal of the parathyroids abolished the enhancing effect of previous Ca deficiency which had developed during the 2 weeks or more on the low-Ca diet. The rate of $\mathrm{Ca}$ absorption of the parathyroidectomized, Ca-deficient rats was the same as that of the sham-operated, normal rats. 


\section{DISCUSSION}

The results show that the low-Ca diet induced a significant increase in Ca absorption in both the duodenum and jejunum. This phenomenon was observed in the duodenum after $3 \mathrm{~d}$ of Ca deprivation, although the enhancement in absorption was only moderate. After 2 weeks on the low-Ca diet, Ca absorption significantly increased in both the duodenum and jejunum.

Results obtained in vitro have suggested that Ca transport is more pronounced in the duodenum than in the jejunum and that $\mathrm{Ca}$ is actively transported through the duodenal mucosa and passively in the jejunum (Schachter \& Rosen, 1959; Schachter

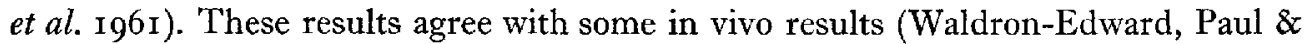
Skoryna, I966), but not with others (Lengemann \& Comar, I96r). We observed a quantitative difference between duodenal and jejunal $\mathrm{Ca}$ absorption. This difference could not have been due to the presence of bile in the duodenum, since Ca absorption was not influenced by previous ligation of the bile duct (Webling \& Holdsworth, 1965 ). However, it was not possible to determine the cause of this difference by the present in vivo method.

A Ca-deficient diet is believed to induce an active transport mechanism along the whole intestine when the diet is supplemented with a sufficient amount of vitamin $D$ (Kimberg et al. I96I). In the present experiments a significant increase was observed in both duodenal and jejunal $\mathrm{Ca}$ transport. These observations do not contradict the above theory and are in accordance with the results of Taylor \& Wasserman (1965, 1967, r969), who found enhanced synthesis of Ca-binding protein along the whole intestine after $\mathrm{Ca}$ deprivation.

Animal experiments (Bronner, 1969; Palmer \& Thompson, r96r) and clinical investigations (Ewe, I968; Nordin, I968; Phang, Kales \& Hahn, I968) suggest that the capacity of the gut to absorb $\mathrm{Ca}$ is limited, although this has not been proved (Dumont, Curran \& Solomon, I959; Zornitzer \& Bronner, 1971). As our results showed, increasing the dose of $\mathrm{Ca}$ injected into the lumen decreased the percentage absorption, but no saturation was observed. The lines in Fig. I suggest that with the lower dose the slope is more pronounced and depends on experimental conditions, whereas with the higher dose the lines seem to run parallel with each other and the rate of absorption depends mainly on the luminal Ca concentration. Ca deficiency influenced only the response at the low-dose levels. This observation can be interpreted to mean that a low-Ca diet increases the capacity of some saturable transport mechanism, but the rate of the passive $\mathrm{Ca}$ diffusion through the intestine is unchanged. However, it should be emphasized that the saturable nature of this process does not prove the presence of an active transport mechanism.

The role of parathyroid hormone in the adaptation of the intestine to a low $\mathrm{Ca}$ supply was investigated by Kimberg et al. (196I). Numerous observations suggest that during $\mathrm{Ca}$ deprivation the activity of the parathyroids is significantly higher (Burkhart \& Jowsey, 1967; Harrison \& Fraser, 1960-r; Potchen \& Watts, 1967; Storey, 1960; Williams, Henderson \& Bowser, 1964). Reports in the literature differ on the significance of the parathyroids in normal absorption of $\mathrm{Ca}$; the effect of para- 
thyroidectomy is greatly influenced by the experimental conditions (Winter, Morava, Simon \& Sós, 1970). As our earlier and present results show, the removal of the parathyroids resulted in only a slight or moderate fall in the rate of Ca absorption in rats given a normal diet. On the other hand, parathyroidectomy significantly diminished intestinal $\mathrm{Ca}$ transport in $\mathrm{Ca}$-deficient rats. In other words, a low-Ca diet failed to promote an increase in $\mathrm{Ca}$ absorption when the parathyroids had been removed. 'This finding conflicts with results of some earlier experiments (Dowdle et al. I960; Kimberg et al. I961). The difference may be due to the fact that the results of the earlier experiments were obtained in vitro with sacs from previously parathyroidectomized rats, whereas the present experiments were done in vivo. A similar discrepancy can be observed in connexion with vitamin D (Urban \& Sched1, I968). The effect of parathyroidectomy was the same whether it had been performed at the beginning or at the end of the dietary regimen, suggesting that the presence of parathyroid hormone is necessary not only for the development of adaptation to a low-Ca diet but also to its maintenance.

\section{REFERENCES}

Bronner, F. (1969). Am. F. clin. Nutr. 22, 376.

Burkhart, J. M. \& Jowsey, J. (I967). Endocrinology 81, 1053.

Dowdle, E. B., Schachter, D. \& Schenker, H. (1960). Am. F. Physiol. 198, 269.

Dumont, P. A., Curran, P. F. \& Solomon, A. K. (1959). J. gen. Physiol. 43, I I I9.

Ewe, K. (1 g68). Klin. Wschr. 46, 66r.

Harrison, H. \& Fraser, R. (1960-I). F. Endocr. 2r, 207.

Kimberg, D. V., Schachter, D. \& Schenker, H. (196r). Am. J. Physiol. 200, 1256.

Lengemann, F. W. \& Comar, C. L. (196r). Am. F. Physiol. 200, ro51.

Melancon, M. J. Jr \& DeLuca, H. F. (r970). Biochemistry, Easton 9, 1658.

Nicolaysen, R. (1956). Acta physiol. scand. 36, I 14.

Nicolaysen, R., Eeg Larsen, N. \& Malm, O. J. (I953). Physiol. Rev. 33, 424.

Nordin, B. E. C. (I968). Gastroenterology 54, 294.

Palmer, R. F. \& Thompson, R. C. (196r). Proc. Soc. exp. Biol. Med. 108, 296

Phang, J. M., Kales, A. N. \& Hahn, T. J. (1968). Lancet ii, 84 .

Potchen, E. J. \& Watts, H. G. (1967). Endocrinology 80, 467.

Schachter, D., Kimberg, D. V. \& Schenker, H. (I96r). Am. F. Physiol. 200, г 263.

Schachter, D. \& Rosen, S. M. (1959). Am. F. Physiol. r96, 357.

Storey, E. (1960). Br. F. exp. Path. 4r, 207.

Taylor, A. N. \& Wasserman, R. H. (I965). Nature, Lond. 205, 248.

Taylor, A. N. \& Wasserman, R. H. (1967). Archs Biochem. Biophys. 119, 536.

Taylor, A. N. \& Wasserman, R. H. ( (969). Fedn Proc. Fedn Am. Socs exp. Biol. 28, 1834.

Taylor, A. N. \& Wasserman, R. H. (1970). Fedn Proc. Fedn Am. Socs exp. Biol. 29, 368.

Urban, E. \& Schedl, H. P. (1968). Clin. Res. 16, 45 I.

Waldron-Edward, D., Paul, T. M. \& Skoryna, C. (1966). Proc. Soc. exp. Biol. Med. I23, 532.

Wasserman, R. H., Corradino, R. A. \& Taylor, A. N. (1969). F. gen. Physiol. 54, no. I, part 2, Ir4 S.

Wasserman, R. H. \& Taylor, A. N. (1968). F. biol. Chem. 243, 3987.

Webling, D. D. \& Holdsworth, E. S. (r965). Biachem. F. 97, 408 .

Williams, G. A., Henderson, W. J. \& Bowser, E. N. (1964). Proc. Soc. exp. Biol. Med. 116, 65 I.

Winter, M., Morava, E., Simon, G. \& Sós, J. (1970). F. Endocr. 47, 65.

Zornitzer, A. E. \& Bronner, F. (1971). Am. F. Physiol. 220, 126r. 